\begin{tabular}{|l|l|l||}
\hline \multicolumn{2}{|c|}{ PublisherInfo } \\
\hline \hline PublisherName & $:$ & BioMed Central \\
\hline \hline PublisherLocation & $:$ & London \\
\hline \hline PublisherImprintName & $:$ & BioMed Central \\
\hline \hline
\end{tabular}

\title{
Wellcome insists on open access
}

\begin{tabular}{|l|l|l||}
\hline \multicolumn{2}{|c|}{ ArticleInfo } \\
\hline \hline ArticleID & $:$ & 5088 \\
\hline \hline ArticleDOI & $:$ & $10.1186 /$ gb-spotlight-20050523-01 \\
\hline \hline ArticleCitationID & $:$ & spotlight-20050523-01 \\
\hline \hline ArticleSequenceNumber & $:$ & 64 \\
\hline \hline ArticleCategory & $:$ & Research news \\
\hline ArticleFirstPage & $:$ & 1 \\
\hline \hline ArticleLastPage & $:$ & 4 \\
\hline \hline & & RegistrationDate : 2005-5-23 \\
\hline ArticleHistory & $:$ & OnlineDate \\
\hline \hline ArticleCopyright & $:$ & BioMed Central Ltd2005-5-23 \\
\hline \hline ArticleGrants & $:$ & \\
\hline \hline ArticleContext & $:$ & 130596611 \\
\hline \hline
\end{tabular}




\section{Stephen Pincock}

Email: Stephen@thescientisteurope.com

Britain's Wellcome Trust said that after October 1 of this year, all new grant recipients will be required to post any papers arising from the funded research in an open-access repository.

The trust, the United Kingdom's biggest nongovernment funder of life sciences research, said that grant recipients would need to deposit their papers within 6 months of publication, either with the National Institutes of Health's (NIH's) PubMed Central or with a UK version the Wellcome Trust and others want to establish.

"Everyone, everywhere will be able to read the results of the research that we fund," said Mark Walport, director of the trust, in a statement. "PubMed Central provides a link from research to other papers and sources of data and greatly improves the power and efficiency of research. Digital archives are only as good as the information stored in them. That's why we feel it's important to encourage our researchers along this path - one I hope others will follow."

Existing grant holders have until October 1, 2006, to comply with the open-access requirement, Wellcome said. The lag is to give them time to adjust to the new policy.

Earlier this year, the NIH came under criticism when it announced a similar policy. Under NIH rules, funded investigators are "requested" to deposit papers arising from the research within 12 months. Advocates of open access said the policy was not strong enough; opponents said the new rule would not improve access to research, but place an unreasonable burden on researchers.

"The Wellcome Trust policy is superior to the NIH policy in two key respects," said Peter Suber, a proponent of open access at Earlham College in Richmond, Ind. "First, it's a requirement, not a request. Second, it does not permit delays longer than 6 months. Assuring early, widespread access to important research results is in the funder's interest, the researcher's interest, and the public interest."

There may be a third respect in which the Wellcome policy is superior, Suber said via E-mail. "I'd have to see more details on the policy to be sure, [but] it appears that the Wellcome Trust is making deposit in PMC (or UK PMC) a simple condition of funding. If so, it's a contractual obligation of the grantee made prior to any copyright transfer agreement with a publisher. Hence, the grantee's publisher would have no standing to interfere."

A spokesman for the trust confirmed that the new policy would make archiving within 6 months a grant condition. Roughly 3500 papers each year arise from Wellcome Trust - funded research, and the new policy means that after October 2006, all of those will be freely available within 6 months of publication. "If journals want to publish some of those... they'll have to accept that," he said.

Stevan Harnad, an advocate of open access at the University of Southampton, UK, said there were problems with the Wellcome approach. "Wellcome's policy of requiring self-archiving is a great improvement over NIH's requesting it," Harnad said in an E-mail. "However, requiring it to be deposited in PMC or UKPMC is a big and unnecessary strategic mistake." 
Wellcome should have required researchers to deposit articles in a repository held by his own institution, from which it could be harvested by PubMed Central or its UK version, Harnad said. "That would have greatly increased the influence of the Wellcome policy, touching on all disciplines and all institutions, not just the biomedical research that Wellcome funds. It would have helped propagate a standard, universal practice in all researchers' institutions, one that could be performed by all researchers in all fields at all institutions."

Harnad also said the Wellcome Trust should have required immediate deposit upon acceptance for publication. "Research progress is not based on 6 or 12 months delay in access to research findings," he said.

Responding to this criticism, the Wellcome Trust spokesman told The Scientist: "We would prefer immediate release, but we're allowing a 6-month delay because we realise this is a big step and we have to approach it in a pragmatic way."

Meanwhile, Research Councils UK (RCUK), an umbrella group for Britain's government science funding councils, is expected to announce its own open-access policy in coming days. People following the development of that policy have told The Scientist that it requires author archiving in repositories where they exist, but does not require the establishment of such archives.

"In contrast to the NIH/Wellcome embargo policy... RCUK looks as if it might adopt the optimal policy (the one recommended by the UK Select Committee last year and already adopted by Scotland)," Harnad said. That policy is "to require immediate institutional self-archiving [with central self-archiving as an option only if the institution does not yet have an institutional repository]."

However, Suber pointed out that when researchers do not have deposit rights at either kind of repository, then a policy to mandate open-access archiving will simply not apply, creating gaps in the policy's coverage. "That's a reason for a funding agency to use a central repository - if not for all grantees, then at least as a fallback," he said.

\section{References}

1. S. Pincock, "UK PubMed Central proposed," The Scientist, May 12, 2005., [http://www.thescientist.com/news/20050512/02]

2. T. Agres, "NIH announces 'open-access' rules," The Scientist, February 4, 2005., [http://www.thescientist.com/news/20050204/02] 
3. Peter Suber, [http://www.earlham.edu/ p peters/]

4. S. Pincock, "UK gov't unsure on open access," The Scientist, February 3, 2005., [http://www.thescientist.com/news/20050203/01]

(C) 2009-2013. SPi Global, Chennai, India. All rights reserved. 